\title{
Geological nature of mineral licks and the reasons for geophagy among animals
}

\author{
Alexander M. Panichev ${ }^{1}$, Vladimir K. Popov ${ }^{2}$, Igor Yu. Chekryzhov' ${ }^{2}$ Ivan V. Seryodkin ${ }^{1}$, Alexander A. Sergievich ${ }^{3}$, \\ and Kirill S. Golokhvast ${ }^{1,3}$ \\ ${ }^{1}$ Laboratory of animal ecology and protection, Pacific Geographical Institute, Far Eastern Branch of the Russian Academy of \\ Sciences, 690041, 7 Radio street, Vladivostok, Russia \\ ${ }^{2}$ Far Eastern Geological Institute, Far Eastern Branch of the Russian Academy of Sciences, 690014, \\ 159 100-letie Vladivostoku avenue, Vladivostok, Russia \\ ${ }^{3}$ Far Eastern Federal University, 690950, 8 Sukhanova street, Vladivostok, Russia \\ Correspondence to: Kirill S. Golokhvast (golokhvast.ks@dvfu.ru)
}

Received: 13 August 2016 - Discussion started: 27 September 2016

Revised: 24 March 2017 - Accepted: 5 April 2017 - Published: 7 June 2017

\begin{abstract}
In this paper, the reasons for geophagy (the eating of rocks by wild herbivores) in two regions of the eastern Sikhote-Alin volcanic belt are considered. The mineralogical and chemical features of the consumed rocks, as well as the geological conditions of their formation, are investigated. A comparative analysis of the mineral and chemical composition of the consumed rocks and the excrement of the animals, almost completely consisting of mineral substances, is carried out. It is established that the consumed rocks are hydrothermally altered rhyolitic tuffs located in the volcanic calderas and early Cenozoic volcano-tectonic depressions. They consist of 30-65\% from zeolites (mainly clinoptilolites) and smectites, possessing powerful sorption properties. According to the obtained data, the main reason for geophagy may be connected with the animals' urge to discard excessive and toxic concentrations of certain elements that are widespread in specific habitats and ingested with forage plants.
\end{abstract}

\section{Introduction}

A new term, "kudur", borrowed from the lexicon of Asian nomad tribes, is analogous to the archaic Russian term "animal salt lick" and defines a natural landscape complex featuring the outcrops of mineral soils, which are systematically consumed by animals and, in some cases, by humans (Panichev, 2011; Panichev et al., 2013; Young, 2011). The term "kudurites" emerged from "kudur", and it specifies all of the varieties of natural mineral soils consumed by animals in kudurs.

The majority of kudurs can be divided into two types - hydromorphic and lithomorphic (Panichev, 1990). Hydromorphic kudurs are formed by running mineral water springs; specifically, clay rocks saturated with chemical elements become kudurites in a water discharge area. A lithomorphic kudur is an exposure of specific rocks that are actively searched for and consumed by animals. The reason why animals eat kudurites is not obvious in the majority of cases: this problem is still challenging and demands a comprehensive scientific explanation.

The importance of the study of kudurs and kudurites becomes obvious if we recall that it is linked to the fundamental problem of the interaction of living systems with minerals (including minerals' contribution to the origin of life). This problem can be applied to the contemporary scientific fields of practical medicine, ecology, and animal breeding technologies.

The presence of kudurs, from the modern point of view, indicates the significance of certain unknown conditions (probably biogeochemical in nature) that are necessary to sustain herbivorous life in specific habitats. Kudurs are a very important constituent of many reserves, national parks and other protected areas. The most notable nature reserves containing kudurs that attract large numbers of hoofed mammals are Yellowstone National Park in the USA and the Ngorongoro 
Conservation Area in Tanzania (Africa) (Panichev, 2011). As we know, both of these parks border giant large calderas of late Cenozoic volcanoes.

Natural landscapes, including kudurs, are widely distributed within the territory of Eurasia, including Russia. The majority of such landscapes are located within protected areas. Extensive kudurs are known to be situated within the Caucasian State Biosphere Nature Reserve. There are also numerous kudurs in most of the reserves of the Altai-Sayan region, the western bank of Lake Baikal, and the Taymyr Peninsula, as well as in the Sikhote-Alin mountains.

This paper is written with the goal of introducing specialists with an interest in kudurs and geophagy to the results of the 2005-2008 and 2010-2012 detailed biological and geological research conducted within two areas of the eastern Sikhote-Alin, Far East, Russia. We chose these two areas because they represent the typical geological-landscape situations associated with the appearance of kudurs in these volcanic mountains (Elpatievsky and Panichev, 1980).

\section{Materials and methods}

We were given permission to undertake sampling from the management of the Sikhote-Alinsky Biospheric Reserve. Confirmation was signed by the director of the reserve, D. G. Gorshkov.

We chose Vanchinskaya, a rift-related coal-bearing basin near the intersection of the Milogradovka and Ussuri rivers (the south-eastern part of the Primorsky region; Fig. 1, area no. 1), as well as the Solontsovsky palaeovolcano in the Sikhote-Alin biosphere nature reserve (the north-eastern part of the Primorsky region; Fig. 1, area no. 2) as examples of typical structures for this detailed research.

In studies of kudurs and kudurites, we are dealing with objects that have both a biological and geological content at the same time; thus, their effective study is possible only by adopting interdisciplinary approaches that bring together the efforts of biologists and geologists, specifically volcanologists, petrologists and geochemists. This explains the specific combination of the general biological approaches with the common geological methodologies and approaches in this work.

During the fieldwork, we studied the landscape peculiarities of the kudur complexes and surrounding territories, and collected kudurites and the parental rocks along which they form as well as coprolite (lithified animal excrement) samples. The collected rock samples and coprolites were studied and tested in the laboratory.

Thin sections were cut from the collected rock samples that were then studied under a polarised optical microscope in the Geochemical Laboratory of the Far Eastern Geological Institute, Far Eastern Branch of the Russian Academy of Science.

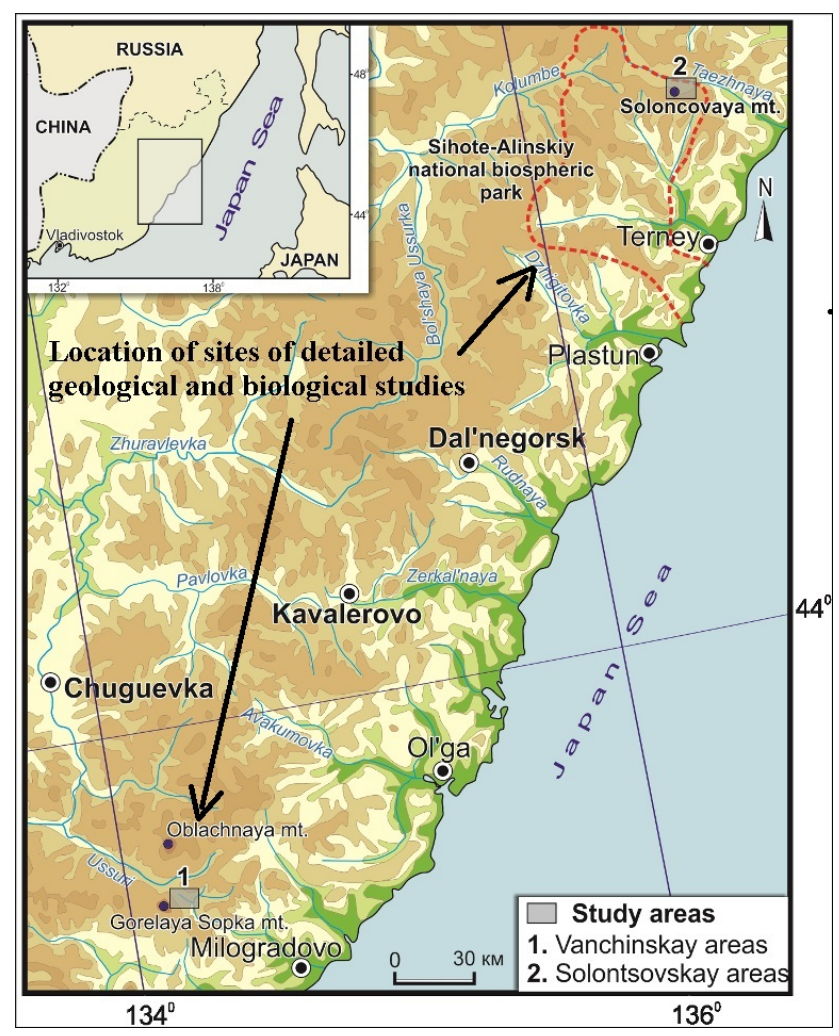

Figure 1. Location of sites of detailed geological and biological studies around the Vanchinsky coal-bearing basin (area no. 1) and in the area of the Solontsovsky palaeovolcano (area no. 2).

Fifty samples of rocks and two samples of coprolites (the Vanchinsky coal-bearing basin (area no. 1) and in the area of the Solontsovsky palaeovolcano (area no. 2)) were analysed in the analytical centre of the Far Eastern Geological Institute by inductively coupled plasma mass spectrometry (ICP-MS) using an Agilent 7500 instrument and by X-ray phase spectroscopy (principal investigator: N. V. Zarubina). Eight samples from the Solontsovsky area and two from the Vanchinsky area were sent to the Mineral Crystal Chemistry Laboratory of the Belov Institute of Geology of Ore Deposits (Russian Academy of Science) to determine their quantitative mineral composition. The mineral structure of unknowns was diagnosed by comparing the experimental and reference spectra from the PDF-4 database using the software package Jade-6.5 (MDI Company). The quantitative analysis was carried out using the absorption coefficient method described elsewhere (Pushcharovsky, 2000). A Rigaku D/Max-2200 diffractometer was applied (investigator: V. V. Krupskaya).

Finally, 10 kudurite samples and two coprolite samples were studied under a Hitachi S-3400N electronic microscope with a Thermo Scientific energy-dispersive system at the Far Eastern Geological Institute (Far Eastern Branch of the Russian Academy of Science). 


\section{Results and discussion}

\subsection{Landscape characteristics of the research areas}

The Vanchinskaya coal-bearing basin is situated near the division watershed of the Sikhote-Alin range of mountains. The majority of this area is located in the Vanchin-Ugolnyi river valley (right tributes of the Milogradovka River). In terms of relief, the Vanchinskaya Basin is a wide and relatively flat basin, approximately $15 \mathrm{~km}$ long with an average width of $5 \mathrm{~km}$. To the north and north-west, this basin is adjacent to the Berezovskaya coal-bearing basin situated in the Ussuri river floodplain to the south of Mount Oblachnaya, one of the highest peaks of the Sikhote-Alin range. The basins are divided by a modest watershed area with a relative height of approximately $100 \mathrm{~m}$ (the absolute height of the swell is approximately $600 \mathrm{~m}$ ). To the south-west, the Vanchinskaya Basin is bound by a tectonic scrap, welldefined in relief, with an average height relative to the bottom of the basin of approximately $500 \mathrm{~m}$. The maximum elevation of the scrap is $1471 \mathrm{~m}$ (Mount Gorelaya Sopka).

Remnants of the Solontsovsky palaeovolcano are situated on the eastern slope of the Sikhote-Alin, within the borders of the Terneisky administrative district in the Primorsky region. The total area of the lithocomplexes related to the Solontsovsky palaeovolcano is approximately $300 \mathrm{~km}^{2}$, of which two-thirds is situated on the right bank of the Tayozhnaya River in the Sikhote-Alin State Biospheric Reserve.

The Solontsovsky palaeovolcano does not stand out much in relief. It builds up a modest low mountain range on the eastern slopes of the Sikhote-Alin range with elevations from 400 to $1100 \mathrm{~m}$. Mount Solontsovaya has the highest elevation of the volcanic remains $(1160 \mathrm{~m})$.

More than $90 \%$ of the territories under consideration are occupied by forest, with significant vertical zoning. Up to $600 \mathrm{~m}$ in elevation, cedar and broad-leaved forests of Korean pines (Pinus koraiensis) and Mongolian oaks (Quercus mongolica) prevail. Fir-spruce forests dominate the mountain slopes in the elevation interval from 600 to $1000 \mathrm{~m}$. At elevations above $1000 \mathrm{~m}$, stone birch forests take over, followed by sub-alpine-type shrubs. Larch and birch-larch forests prevail in the flat watershed areas close to the Vanchinskaya Basin.

Brown mountain-forest soils and brown taiga illuvialhumic strongly skeletal acidic soils are typical for the described areas. The soil profile is morphologically poorly differentiated into genetic horizons. Frequently, one can find localities with rock slides or crushed stone soil that are almost devoid of humus.

The typical species of herbivorous hoofed animals inhabiting both study areas are the Far Eastern red deer (Cervus elaphus) and the musk deer (Moschus moschiferus). Roe deer (Capreolus pygargus) are seasonally present (making sharp seasonal migrations into the territory). Of these, the main visitor to the kudurs is the Far Eastern red deer. Roe deer only extremely rarely make visits to the kudurs. Musk deer show

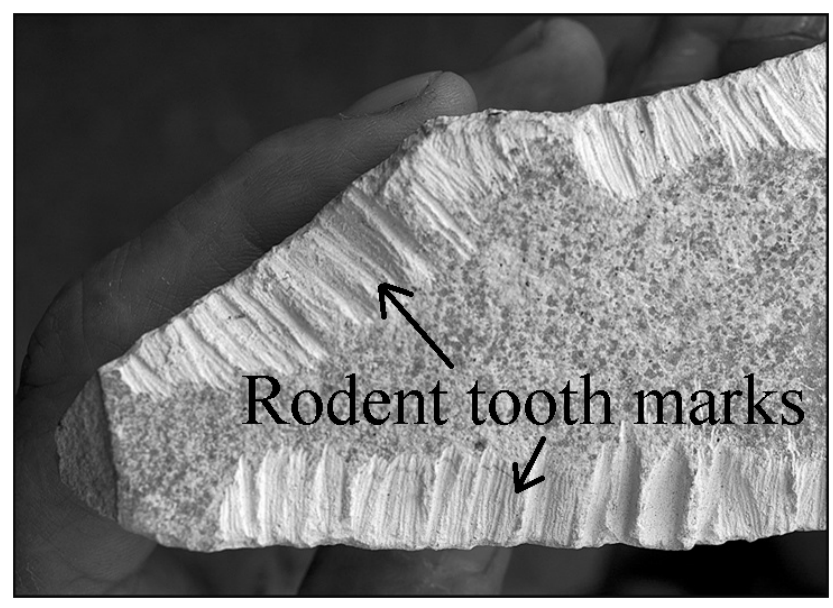

Figure 2. Rodent tooth marks on a dense zeolitic rhyolite tuff. Sample from a kudur in the Chetvertyi stream basin (the Solontsovsky palaeovolcano area).

no evidence of visiting the kudurs, which is undoubtedly connected to nutritional differences among these herbivorous animals. It is known that the musk deer diet is dominated by epiphytes, whereas the Far Eastern red deer prefers herbaceous plants and shrubs. Thus, it is obvious that the kudurs are visited by those animals that have a closer connection with bedrocks.

Not long ago, before the 1980s, an additional species of hoofed animal inhabited the territory of the Solontsovsky palaeovolcano and actively visited kudurs: the moose (Alces alces). Currently, there are no moose in this area, possibly due to the shift in the habitat borders of this species to the north in response to the general trend of climate warming in the region.

Apart from hoofed animals, the blue hare (Lepus timidus), squirrel (Sciurus vulgaris), northern pika (Ochotona mantchurica) and mouse-like rodents (mice, field voles) also not infrequently visit kudurs, leaving distinctive teeth marks on the stones. Figure 2 shows a distinctive sample of exposed bedrock with the teeth marks of a mouse-like rodent, gathered from one of the kudurs in the Solontsovsky volcano area.

Kudurs, because they are gathering sites for hoofed animals, often attract large predators. These are most commonly brown bears (Ursus arctos), sometimes tigers (Panthera tigris), and, rarely, wolves (Canis lupus).

As demonstrated by our group's research (Zaumislova and Panichev, 1990) and the data of Kaplanov (1948), and as reported by a number of the reserve employees in the "Nature Chronicles", the season in which animals visit kudurs is the entirely snow-free period of the year. The greatest peaks in visits by hoofed animals occur at the end of spring/beginning of summer and at the end of summer/beginning of autumn. At peak times, the number of kudur visits by animals can be dozens per $24 \mathrm{~h}$. During a visit to a kudur, a medium-sized 


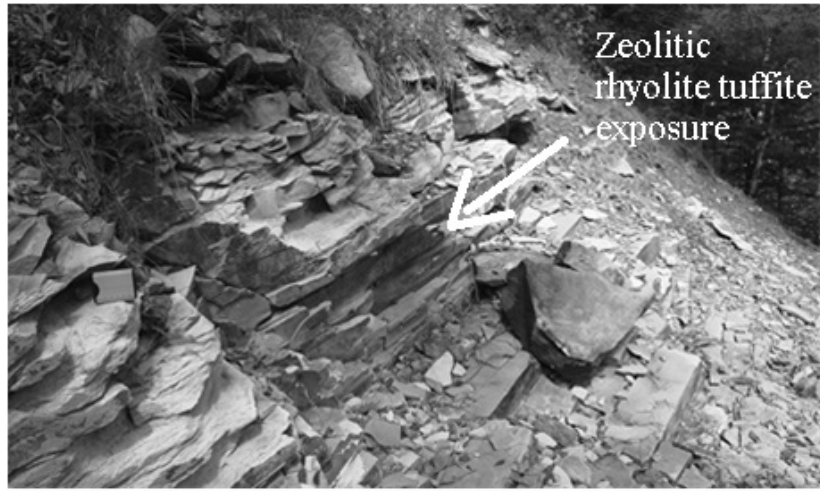

Figure 3. Zeolitic rhyolite tuffite exposure with the marks of active usage of rocks by wild animals (kudur no. 9, the Vanchinskaya coalbearing basin).

Far Eastern red deer usually consumes between several hundred grams to several kilograms of kudurite.

Our field studies as well as the materials of our predecessors show that, in both areas under consideration, there are kudurs that are almost entirely of the lithomorphic type. As a rule, these are relatively dry rock exposures emerging on mountain slopes of various steepness that were created as a result of natural slope erosion processes and the activity of hoofed animals. Sometimes these sites are rock slides with small areas of exposed stone, showing evidence of consumption by animals in the form of recess salt-lick niches in the rock and a peculiar network of approach paths maintained by the animals over an extended period. The typical appearance of the kudurs occurring in the studied territories is shown in Figs. 3, 4, and 5.

It should be emphasised that the kudurs in both areas under consideration are known to have existed for a very long time. The largest of them, for example on the southern slope of Mount Solontsovaya (Figs. 4, 5), have existed almost intact for several hundred years.

An indirect form of evidence that kudurs have existed for centuries may be the nearby presence of archaeological sites with peculiar artefacts. Such a site from the Stone Age, containing numerous hunting arrows and spear heads, was found in the wellhead part of the Vanchin-Ugolnyi stream (Fig. 6). Such sites also exist in the Solontsovsky palaeovolcano area (Fig. 7). The majority of the archaeological sites date back to the late Palaeolithic or early Neolithic age (Kononenko, 1993).

Archaeologists explain ancient man's interest in both territories under consideration as being based on the presence of strongly silicified volcanic rock that was convenient for manufacturing stone implements. It is logical to suppose that these areas also attracted ancient man to go there to hunt the hoofed animals that were visiting the kudurs.

We believe that the lifespan of some kudurs may amount to thousands and even tens of thousands of years; as a matter

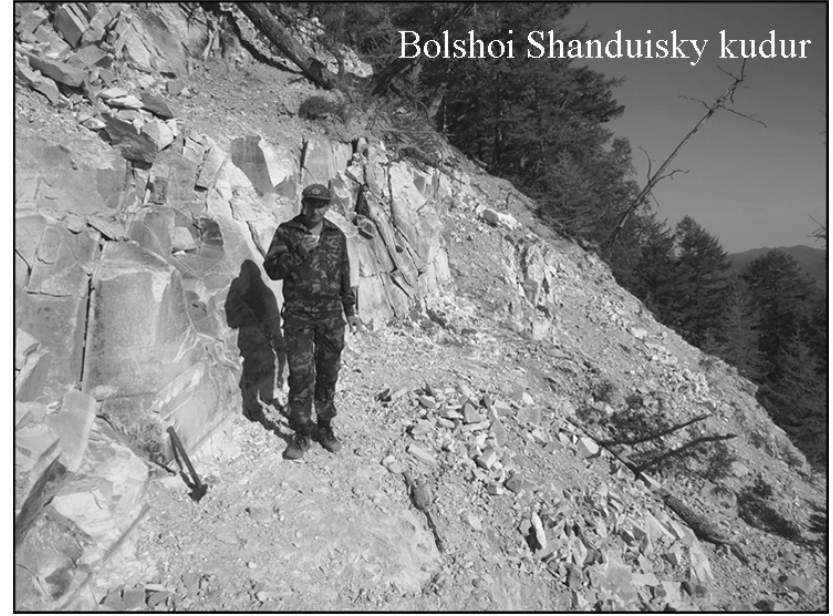

Figure 4. The Bolshoi Shanduisky kudur at the base of Mount Solontsovaya, at the head of the Malyi Solontsovyi stream on a bedrock exposure of the Solontsovsky palaeovolcano caldera sediment. Animals actively eat loosened, weathered and partly clayed landwaste of zeolitic ash tuff and tuffites of rhyolite composition (I. V. Seryodkin in photo).

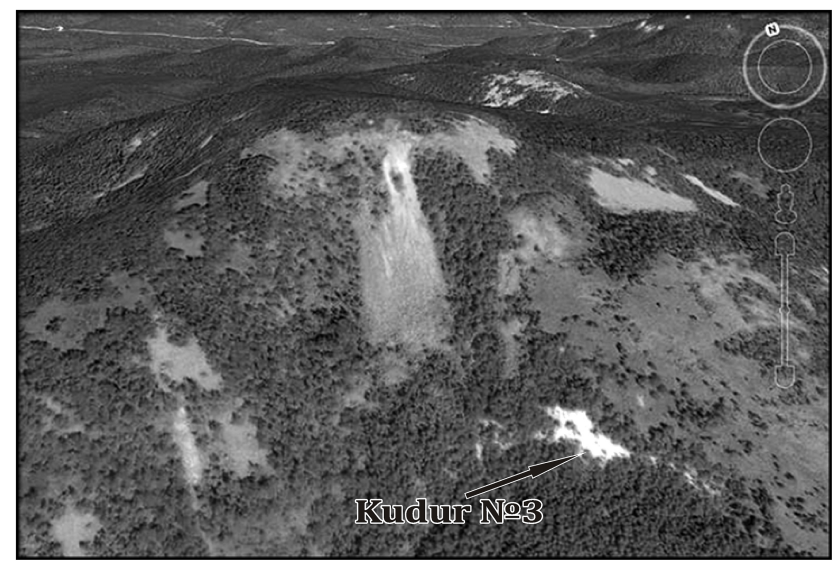

Figure 5. View of Mount Solontsovaya from the south (source: Google Maps). At the base of the mountain, kudur no. 3 (Bolshoi Shanduisky) appears as a white spot.

of fact, these can be time periods of geological scale, during which the given territory was inhabited by large hoofed animals. The lifespan of small kudurs is less significant. The length of their life depends, first, on geological and geomorphological (bulge forming) factors determining the exposure of zeolite-containing rock and, second, on the convenience for wild animals to visit these sites.

The bedrock of a kudur has light, yellowish, greenish or pinkish colours. They are often covered with dark crusts and crystal dendrites of iron and manganese oxide. Outcrops are disintegrated by cracks throughout the stratum. Separate blocks of exposed rock, especially in the radical part of the trees, are often transformed into a loose, grainy mass that re- 

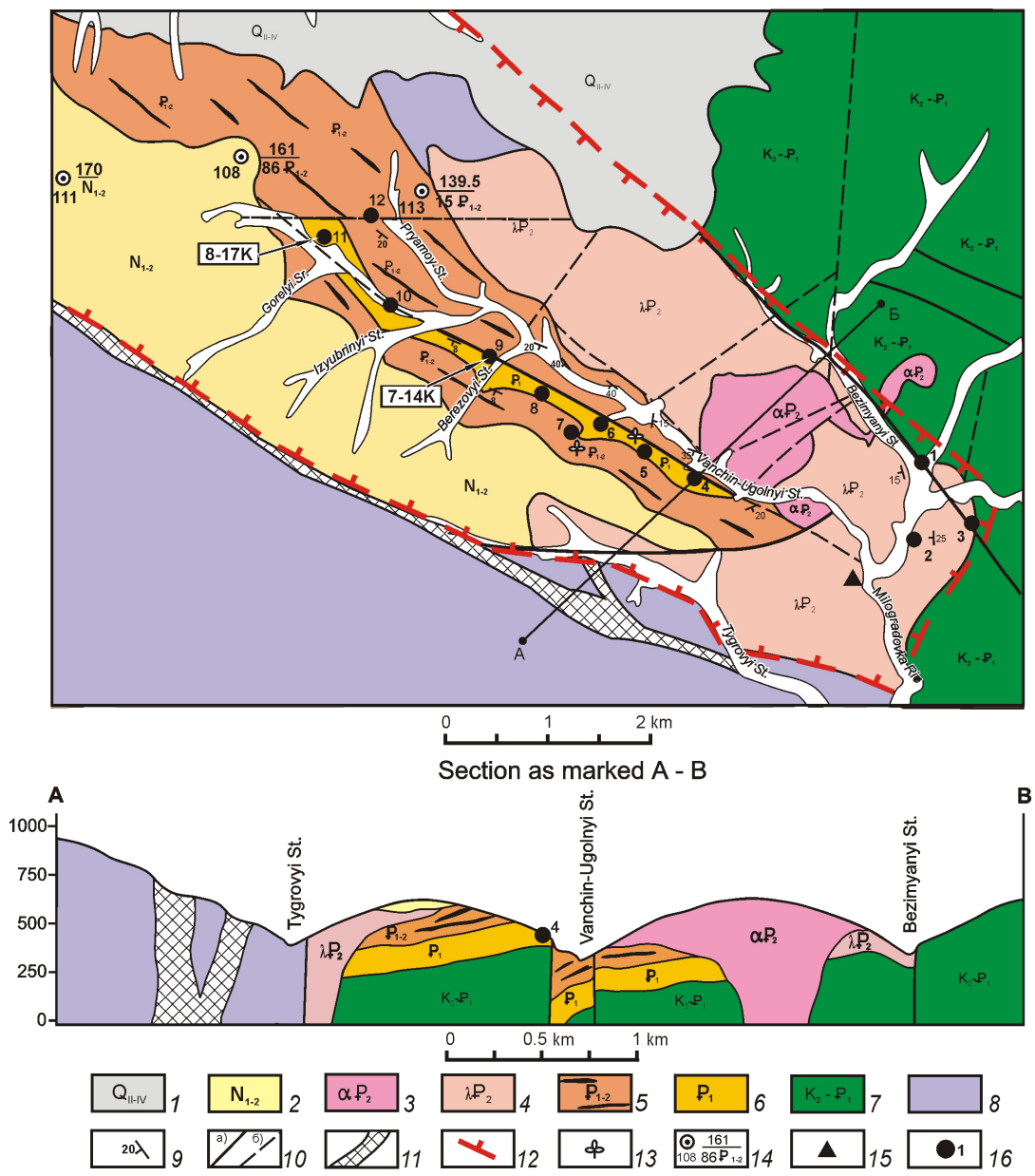

Figure 6. Geological map and transverse cross section of the Vanchinskaya coal-bearing basin: 1 - Quaternary deposits; 2 - Eocene conglomerates and sandstones; 3 - Eocene trachyandesites and trachydacites; 4 - Eocene rhyolites and rhyolite tuff; 5 - Eocene carbon-rich terrigenous and volcano-sedimentary deposits (argillites, siltstones, sandstones, tuffaceous sandstones, conglomerates, sometimes with interbeds of brown coal and rhyolite tuffs); 6 - Palaeocene volcanogenic-sedimentary deposits (tuffaceous siltstones and sandstones with interbeds of rhyolite tuffs); 7 - Upper Cretaceous to Palaeocene poorly defined undifferentiated formations (predominantly felsic to intermediate and mafic volcanic units); 8 - pre-Mesozoic sedimentary and volcanogenic deposits (predominantly siltstones and sandstones); 9 dip and strike of rock; 10 - faults: determined (a), assumed (b); 11 - tectonic breccia zones; 12 - assumed border of the basin; 13 - sampled localities of fossilised flora; 14 - shafts and drill holes; 15 - archaeological site; 16 - the most prominent kudurs.

sembles halva when in a flooded state and appears off-white with different shades of impure dust and a sandy element when in a dry state. Derived secondary kudurites enriched with clay matter can form at the base of bedrock exposures where edge water exudes; they form specific mud and clayed grounds that are "stomped" by the animals with licked deepenings, which appear as a result of the animals licking the clay rocks. Often, there are layers containing the fossils of plants, some of which are coalificated, in Vanchin kudurites.

\subsection{Brief geological characteristics of the research areas}

In the Late Cretaceous and Cenozoic, the continental blocks of Sikhote-Alin were affected by rifting and magmatism
(Otofuji et al., 1995, 2002). A prominent episode of ignimbrite volcanism took place in the Late Cretaceous (Turonian to Campanian; 90-75 Ma) and in the first half of the Palaeogene (Palaeocene-Eocene; 65-45 Ma) (Grebennikov et al., 2014).

The former period of time ( $\sim 90-75 \mathrm{Ma})$ is characterised by a thick plateau of ignimbrites of so-called Primorskaya formation, which is a part of the Sikhote-Alin volcanic belt. The Primorskaya formation is subdivided into tuffs, rhyodacitic and rhyolitic ignimbrites, which were formed due to caldera eruptions from shallow felsic magma reservoirs. The distinctive feature of the ignimbrites is a high content (40$60 \%$ ) of crystal clusters of quartz and a plagioclase up to $1 \mathrm{~cm}$ in size. Dark-coloured minerals are biotite and hornblende. Accessory minerals are magnetite and, rarely, apatite, 
zircon and allanite. Intrusive analogues of the plateau ignimbrites are granites of the Primorskaya formation, which are outcropped at eroded volcanic centres. They belong to calc-alkaline and alkaline rock series. On the upper crust normalised trace element diagram they show distinct minima of $\mathrm{Nb}, \mathrm{Sr}, \mathrm{Zr}, \mathrm{Ti}$ and maxima of $\mathrm{K}, \mathrm{Th}, \mathrm{La}$ and $\mathrm{Ce}$. According to the discrimination diagram of granitic rocks (Pearce et al., 1984) the granites and ignimbrites of the Primorskaya formation fall into the fields of the volcanic arcs and syn-collision granites (Popov et al., 2006; Grebennikov and Popov, 2014).

In the latter period of time $(\sim 65-45 \mathrm{Ma})$, rift structures of the EW and SE-NW orientation formed. Sediments in the rift depressions are often coal-bearing. Igneous formation of this age is located within the depressions and calderas. It is represented by basalts, ignimbrites, baked tuffs, volcanic glasses and rhyolites (often in the form of extrusive domes) of the Yakutinskaya, Solontsovsky and Buinskaya volcanic structures and Bogopolsky granitic complex (Fig. 1). The orientation of the magma conduits in concordance with the rift orientation testifies to the conditions of continental extension. The youngest depressions (e.g. the Vanchinskaya (Fig. 1), Zerkalnensky and Kraskinsky depressions) were formed $\sim 47-45 \mathrm{Ma}$ as dated by coeval fissure eruptions of basalts and rhyolites (Chekryzhov et al., 2010).

\subsection{History of the Vanchinskaya coal-bearing basin formation}

The Vanchinskaya coal-bearing basin, in accordance with the State Geological Survey stratigraphic scheme accepted in the 1960s, is filled by the Eocene volcanogenic coal-bearing sediments and the Oligocene and Miocene volcanic formations. Volcanics intercalated with aquifer sediments are highly altered to zeolite-rich rocks. The highly altered zeolite-bearing rocks were recorded within unconfined aquifer layers of volcanogenic sediments. At the end of the 1980s, Seredin, a researcher from the Institute of Geology of Ore Deposits of the Russian Academy of Science, discovered coal layers with a high concentration of rare-earth elements (Seredin and Shpirt, 1999) while studying the geochemistry of Vanchinskaya Basin coal.

Our research on the Vanchinskaya Basin included stratigraphic investigation involving the study of palaeoflora imprints and palynological research. The data obtained allowed us to reconstruct the geological history of the Vanchinskaya Basin along with the stages of its volcanism, the impact on sedimentation and the hydrothermal alteration (Chekryzhov et al., 2010). As a result, we were able to define the geological patterns of kudur formation and their position in the Vanchinskaya depression, and then we applied these patterns to the evaluation of other Sikhote-Alin territories.

According to our reconstruction, during the initial stages of its formation, the Vanchinskaya Basin was a closed intermountain basin with a steep south-western tectonic wall and a gently sloping north-eastern wall. Such a structure could be considered as a half-graben. The lake basin within it was a major storage area for terrigenous and volcaniclastic sediments. The data obtained prove that the basin started to form in the Palaeocene $(\sim 65-50 \mathrm{Ma})$.

A large portion of the erupted material (volcanic ash and pumice) was stored in the lake basin, as evidenced by the interbeds of vitroclastic tuffs and volcanic sands deposited in the water.

Felsic magma eruptions from near-surface magma chambers ended approximately at $43 \mathrm{Ma}$ in the form of a small extrusion of andesitic melt on the north-eastern bank of the basin (Chekryzhov et al., 2010). Its fragments, including explosive tuff conglomerates, lava flows and extrusive bodies of glassy trachyandesites, were currently outcropped. The final stages of the bimodal (rhyolite and trachyandesite) volcanism were associated with intensive alteration to the rocks near the thermal springs along the north-west-striking faults. Glassy volcanics in the regions around the thermal springs were metasomatically modified into smectite, zeolite and opalrich rocks. Within the aquifers of the basin, the whole mass of tuffaceous and sedimentary rocks experienced strong hydrothermal alteration. Post-volcanic processes were responsible for the formation of gold and silver ores at the Soyuznoe deposit within the Soyuznensky palaeovolcano (northeastern side of the depression), as confirmed by the K-Ar dating of the adularia from quartz-adularia veins with gold and silver mineralisation (Tomson et al., 2002).

Final relief-forming processes took place between the late Miocene and the Pleistocene. This was especially true for the areas of the junction of major ridges and the sublatitudeoriented tectonic zones. The Milogradovskaya tectonic zone is an example.

The changes in relief were accompanied by a shift of the main divide of the Sikhote-Alin range and reorganisation of the drainage pattern of the Ussuri River (Korotkiy, 1968). As a result, the terraces of the Vanchin-Ugolnyi palaeovalley were "hanging" on the modern valley walls $(50 \mathrm{~m}$ high and more), creating a specific intermittent structural bench that is located $300 \mathrm{~m}$ away from the modern stream (Fig. 6). This bench enabled the exposure of zeolite- and clay-bearing rocks along the volcanic and sedimentary deposits at the right wall of the valley. Some of those exposed areas were formed by specific kudur landscapes.

\subsection{Geology and study history of the Solontsovsky volcano}

In 1971, Bykovskaya was the first to identify the tuff mass of rhyolites with horizontal volcanic and sedimentary deposits in the middle current of the Tayozhnaya River as a separate stratigraphic unit called the "Solontsovskaya unit". As a result of further geological investigations in this area (Vetrennikov, 1976), it was discovered that the rocks in that mass represented the ruins of a volcanic structure (Fig. 7) that had 


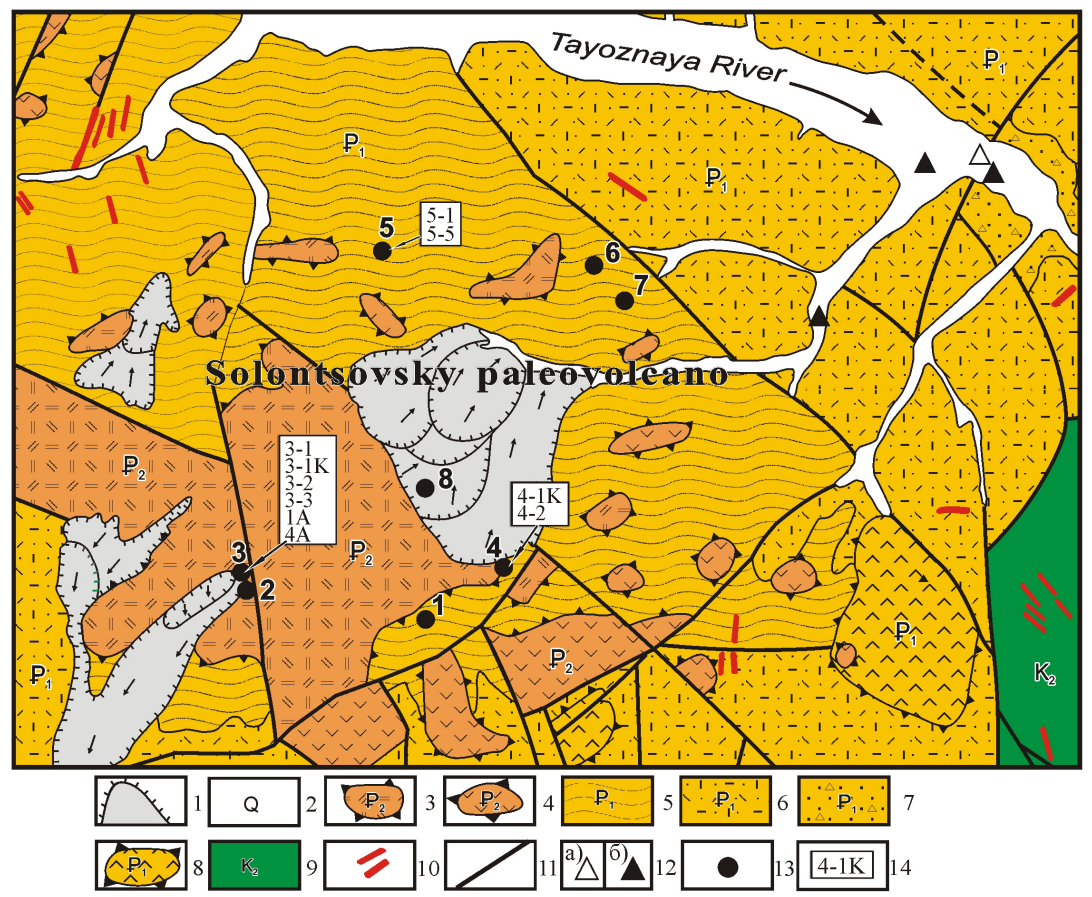

Figure 7. Geological scheme of the Solontsovsky palaeovolcano (Panichev et al., 2012, with additions): 1 - undivided Quaternary landslide deposits (arrows mark the direction of the slide motion); 2 - Quaternary alluvial deposits (sands, clay, gravels); 3-4 - Eocene extrusive bodies of trachyrhyolites (3) and dacites (4); 5-7 - Palaeocene volcanogenic and volcano-sedimentary formations of the Solontsovskaya unit: pelitic and psammitic tuffs of rhyolites with plant detritus, tuffites, tuff siltstones, tuffaceous sandstones with layers of banded silicites of the upper subunit (5); ignimbrites and welded tuffs of rhyolites, psammitic tuffs of rhyolites of the transitional subunit (6); ignimbrites and psephitic and psammitic tuffs of rhyolites, lower subunit tuffites (7); 8 - Palaeocene andesite; 9 - tuffs, tuffites, ignimbrites of the Primorsky Suite rhyolites, the Turonian and Santonian ages; 10 - Eocene andesite subvolcanic bodies and dikes; 11 - faults; 12 - archaeological sites of the Bronze (a) and Mesolithic (b) ages; 13 - kudurs; 14 - sampling localities.

been called the "Solontsovsky palaeovolcano or calders" by Vetrennikov.

According to Vetrennikov (1976), the Solontsovsky volcano began to form around $80 \mathrm{Ma}$. The first data obtained via the $\mathrm{K} / \mathrm{Ar}$ dating of volcanic rocks indicate a younger age of 61-56 million years (Panichev et al., 2012).

The basement of the palaeovolcano is composed of coarse tuff conglomerates bedded with agglomerated rhyolitic tuffs. During subsequent caldera-forming stages of the volcanism, these were covered by an extensive layer of welded rhyolite tuffs and ignimbrites. Residual hills of these layers remain in the highest parts of the structure where the Zabolochennaya and Tayozhnaya rivers divide. Within the caldera, there is a rock mass on the bed of the ignimbrites; these rocks could have been created in the lacustrine environment of the caldera's central part fed by multiple thermal springs.

The upper subunit of stratified deposits consists of lacustrine and caldera formations. The rocks are primarily thin re-deposited dust tuffs, sometimes tuffites, created in water with subsequent diagenetic alteration of the volcanic glass particles. All kudurs examined in the area turned out to be confined to that upper subunit of the Solontsovskaya unit, namely to light grey, white or yellowish zeolite-bearing rhyolitic tuffs (mostly ash tuffs, sometimes with layers of tuffites).

\subsection{Mineralogy and petrography of kudurites}

According to X-ray diffraction analysis (Table 1), all kudurites and their source rocks have a substantial content of zeolites (35-65\%). Apart from zeolites, kudurites contain clay minerals (up to $26 \%$ ) as well as different types of silica (tridymite, christobalite, quartz; 3-25\%) and traces of feldspars, actinolite and goethite.

The mineral compositions of all kudurites within the Vanchinskaya Basin is identical with $40-70 \%$ of zeolites being the heulandite and clinoptilolite types, occasionally with the addition of mordenite and stilbite, and clay minerals of the smectite group (up to $40 \%$ ) with traces of quartz and feldspar. One of the kudurite samples contained a significant addition of adular along with the zeolitic vitroclastic tuffs. Another sample, collected where zeolitic tuff siltstones are in direct contact with a coal layer, also exhibited kaolinitechlorite alterations. 
Table 1. The results of the quantitative X-ray phase analysis of kudurites and source bedrock.

\begin{tabular}{|c|c|c|c|c|c|c|c|c|c|c|c|c|c|c|c|}
\hline \multirow[b]{2}{*}{$\frac{\tilde{d}}{\tilde{\Xi}}$} & \multicolumn{5}{|c|}{ Zeolites } & \multicolumn{2}{|c|}{ Clay rock } & \multicolumn{8}{|c|}{ Other minerals } \\
\hline & $\begin{array}{l}\frac{0}{0} \\
: \frac{0}{0} \\
\frac{0}{0} \\
\frac{0}{0}\end{array}$ & 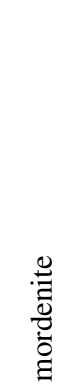 & 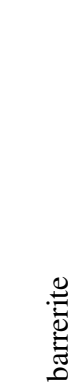 & 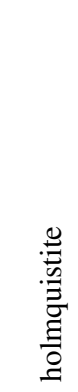 & $\frac{\stackrel{y}{0}}{\frac{\tilde{d}}{80}}$ & 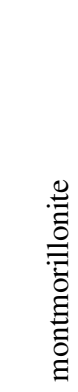 & $\stackrel{\Xi}{\Xi}$ & $\begin{array}{l}\stackrel{\Xi}{\Xi} \\
\stackrel{\Xi}{\Xi} \\
\stackrel{\Xi}{\Xi}\end{array}$ & 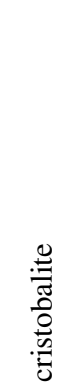 & 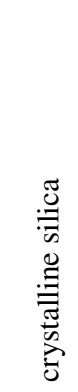 & 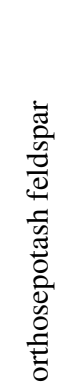 & 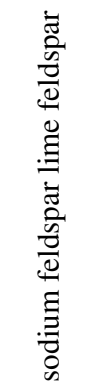 & 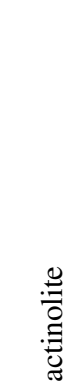 & 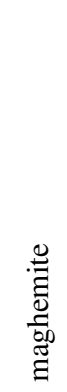 & \\
\hline $3-1$ & 45.4 & - & - & - & - & 32.6 & - & - & 1.0 & 1.8 & 9.1 & 2.1 & - & - & - \\
\hline $3-1 \mathrm{~K}$ & 40.2 & - & - & - & - & 25.7 & 3.5 & 4.1 & 3.4 & 1.5 & 7.6 & 8.2 & - & - & - \\
\hline $3-2$ & 47.8 & - & - & - & - & 31.1 & 1.0 & - & 1.0 & 1.7 & 5.5 & 5.7 & - & - & 5.1 \\
\hline $3-3$ & 52.2 & - & - & - & - & 10.8 & 3.2 & - & 2.4 & 1.5 & 8.7 & 7.1 & 11.1 & - & - \\
\hline $4-1 \mathrm{~K}$ & 35.4 & - & - & - & - & 9.0 & 5.3 & - & - & 26.3 & 7.1 & 10.2 & 4.1 & 2.6 & - \\
\hline $4-2$ & 17.5 & - & 14.4 & 16.2 & - & 7.4 & 1.0 & - & - & 17.6 & 7.5 & 18.4 & - & - & - \\
\hline $5-1$ & - & 3.5 & - & - & - & 94.3 & - & - & - & 2.2 & - & - & - & - & - \\
\hline $5-5 \mathrm{~K}$ & 32.0 & - & - & - & 22.7 & 4.5 & 1.0 & 2.9 & - & 26.7 & - & - & 10.2 & - & - \\
\hline $7-14 \mathrm{~K}$ & 46.0 & - & - & - & - & 22.0 & - & - & 2.2 & 15.0 & 1.0 & 14.0 & - & - & - \\
\hline $8-17 \mathrm{~K}$ & 48.8 & - & - & - & - & 36.1 & 1.1 & - & 1.7 & 3.8 & 4.1 & 1.4 & - & - & - \\
\hline
\end{tabular}

Note. 3-1 to 3-3 - Bolshoi Shanduisky kudur: 3-1 - vitric tuff in bedrock, white with yellowish shades, in places with numerous tiny black inclusions of ferrous and manganous oxide, 3-1 K - the same disintegrated in deluvium (kudurite); 3-2 - vitric tuff similar to tuff from the lower subunit; 3-3 vitric tuff similar to the tuff from a different horizon; 4-1 K to 4-2 - kudur 4: 4-1 K - disintegrated tuffite in deluvium (kudurite); 4-2 - pelitic tuffite, debris on the ground; 5-1 to 5-5 K - kudur Nechet: 5-1 - opoka-resembling rock from bedrock deposit in the upper part of rockslide without any marks of consumption by animals, light, white colour with yellowish-brown shading, breaks into plates with shell-like fracturing; 5-5 K - land waste and small debris of vitric tuff in the roots of a larch tree (kudurite). Vanchinskaya Basin: 7-14 K - disintegrated tuffite in the form of interbed at the bedrock exposure, which resembles halva (kudurite), kudur no. 9; 8-17 K - disintegrated vitric tuff at the outcrop (kudurite), kudur 11.

The zeolites from the Shanduyskiy site (see Table 1) mostly contain clinoptilolite. Some samples contain rare minerals such as barrerite and holmquistite.

Barrerite is a zeolite rich in sodium; for example it is typical of altered ores of the Kamchatka gold-silver deposits (Andreeva and Kim, 2008). The presence of holmquistite is difficult to explain because this rare type of lithium-rich zeolite is more typical for metasomatically modified Li-rich granitoids.

The highest concentration of zeolites was found in the rocks of the Bolshoi Shanduisky kudur. The visible thickness of the subunit related to intensively zeolitic rocks is at least $50 \mathrm{~m}$ (with a zeolite concentration of approximately 40 $52 \%)$. This suggests that the frequency of animal visits to kudurs is closely linked to the kudur's content of zeolites.

The study of thin rock sections facilitated a more accurate identification of the parent rock on which the kudurites had formed and the determination of a number of details about their secondary transformation. The predominant part of such rocks was originally determined as being vitric tuffs of rhyolite composition, pelitic, rarely psammitic in grain size, more often with an insignificant content of crystalloclasts. Zeolites were most actively developing on ashy particles of glass, often fully replacing them with microfelsitic aggregates, which are very clearly seen under a polarised microscope (Fig. 8a). Pelitic materials were most actively formed in the interim between large ashy particles, replacing the thinnest matrix of cementing mass. In some areas, vitric tuffs with a high concentration of zeolites were fully transformed into a microfelsitic mass consisting almost completely of zeolite (Fig. 8b).

\subsection{Major and trace element composition of host rocks and kudurites}

The volcanic rocks from which the kudurites are forming within the borders of the Vanchinskaya Basin belong to the high-potassic dacite-rhyolite series. The obtained K/Ar dating on rhyolite ( $44.7 \pm 1.0 \mathrm{Ma}$ ) (Chekryzhov et al., 2010) indicates their younger age compared to similar rocks from the Solontsovsky palaeovolcano. Zeolitic rocks (perlite and perlitic tuffs) contain a much lower amount of alkalis compared to unaltered rhyolites and rock glasses. The chemical compositions of zeolitic perlite, perlitic tuffs and tuffaceous sandstone from different parts of a transverse section of the volcano-sedimentary deposits are very similar.

Solontsovsky volcano rocks are represented by highpotassic rhyolites of the calc-alkaline series. Thin vitric tuffs in the upper part, including zeolitic variations, turned out to 
Table 2. Chemical (mass \%) and microelement $\left(\mu \mathrm{g} \mathrm{g}^{-1}\right)$ composition of the studied kudurites' parent bedrocks and coprolites.

\begin{tabular}{|c|c|c|c|c|c|c|c|c|c|c|c|}
\hline \multirow[t]{2}{*}{ Element } & \multicolumn{9}{|c|}{ Solontsovsky volcano } & \multicolumn{2}{|c|}{ Vanchinskaya Basin } \\
\hline & $2-1 \mathrm{~K}$ & $3-1 \mathrm{~K}$ & $3-3$ & $3-2$ & $4-1 \mathrm{~K}$ & $4-2$ & $5-5$ & $1 \mathrm{~A}$ & $4 \mathrm{~A}$ & $7-14 \mathrm{~K}$ & $8-17 \mathrm{~K}$ \\
\hline & \multicolumn{7}{|c|}{ kudurites } & \multicolumn{2}{|c|}{ coprolites } & \multicolumn{2}{|c|}{ kudurites } \\
\hline $\mathrm{SiO}_{2}$ & 63.39 & 67.36 & 67.07 & 66.27 & 61.81 & 67.30 & 66.47 & 60.62 & 56.12 & 64.85 & 64.88 \\
\hline $\mathrm{TiO}_{2}$ & 0.74 & 0.11 & 0.13 & 0.16 & 0.55 & 0.14 & 0.19 & 0.17 & 0.17 & 0.32 & 0.43 \\
\hline $\mathrm{Al}_{2} \mathrm{O}_{3}$ & 19.18 & 11.93 & 12.16 & 12.51 & 16.55 & 13.54 & 14.32 & 11.78 & 10.92 & 13.60 & 12.83 \\
\hline $\mathrm{Fe}_{2} \mathrm{O}_{3}$ & 2.80 & 1.86 & 1.48 & 1.34 & 4.12 & 1.83 & 1.14 & 1.44 & 1.43 & 2.33 & 2.89 \\
\hline $\mathrm{MnO}$ & 0.05 & 0.02 & 0.03 & 0.03 & 0.05 & 0.02 & 0.10 & 0.22 & 0.10 & 0.03 & 0.13 \\
\hline $\mathrm{MgO}$ & 0.53 & 0.28 & 0.24 & 0.22 & 1.03 & 0.28 & 0.21 & 0.40 & 0.53 & 1.42 & 0.13 \\
\hline $\mathrm{CaO}$ & 4.34 & 1.03 & 1.24 & 1.23 & 3.66 & 1.31 & 1.08 & 1.84 & 2.10 & 0.60 & 0.63 \\
\hline $\mathrm{Na}_{2} \mathrm{O}$ & 4.68 & 1.81 & 2.21 & 2.62 & 3.06 & 2.23 & 1.85 & 1.18 & 1.01 & 2.42 & 1.99 \\
\hline $\mathrm{K}_{2} \mathrm{O}$ & 1.93 & 3.64 & 3.87 & 3.92 & 2.10 & 3.75 & 4.28 & 5.68 & 4.62 & 3.38 & 2.78 \\
\hline $\mathrm{P}_{2} \mathrm{O}_{5}$ & 0.04 & 0.01 & 0.02 & 0.02 & 0.03 & 0.01 & 0.04 & 0.27 & 0.40 & 0.15 & 0.10 \\
\hline LOI & 2.17 & 11.95 & 11.55 & 6.53 & 4.42 & 5.93 & 8.56 & 16.40 & 22.60 & 7.65 & 9.90 \\
\hline $\mathrm{H}_{2} \mathrm{O}^{-}$ & 0.55 & 4.22 & 5.03 & 5.62 & 2.91 & 3.47 & 2.00 & - & - & 2.80 & 2.83 \\
\hline$\Sigma$ & 100.41 & 100.00 & 99.99 & 100.47 & 100.31 & 99.80 & 100.25 & 99.99 & 100.00 & 99.55 & 99.55 \\
\hline $\mathrm{Ni}$ & 1.21 & 0.00 & 0.00 & 1.98 & 2.43 & 1.40 & 0.45 & 0.00 & 0.00 & 3.67 & 4.02 \\
\hline Co & 3.86 & 0.14 & 1.03 & 0.55 & 3.97 & 0.47 & 0.49 & 1.29 & 0.69 & 1.89 & 2.03 \\
\hline $\mathrm{Cr}$ & 67.04 & 0.00 & 0.00 & 4.02 & 30.12 & 1.00 & 0.65 & 0.00 & 0.00 & 1.00 & 3.50 \\
\hline $\mathrm{V}$ & 39.32 & 3.67 & 5.15 & 5.80 & 42.90 & 5.21 & 4.26 & 7.64 & 8.43 & 3.55 & 3.01 \\
\hline $\mathrm{Sc}$ & 5.60 & 3.49 & 3.92 & 4.40 & 6.73 & 4.20 & 4.10 & 3.79 & 3.27 & 4.37 & 5.22 \\
\hline $\mathrm{Zn}$ & 47.80 & 34.41 & 30.28 & 42.00 & 85.40 & 58.80 & 50.50 & 41.92 & 45.24 & 81.22 & 73.16 \\
\hline $\mathrm{Ga}$ & 18.02 & 17.74 & 15.21 & 12.96 & 15.86 & 12.79 & 12.84 & 13.71 & 12.35 & 37.60 & 23.85 \\
\hline Mo & 3.71 & 0.20 & 0.21 & 0.64 & 2.04 & 0.45 & 0.24 & 1.54 & 0.10 & 0.33 & 0.27 \\
\hline $\mathrm{Rb}$ & 39.28 & 128.63 & 132.13 & 90.77 & 91.47 & 103.62 & 88.77 & 147.08 & 134.18 & 210.00 & 157.33 \\
\hline Cs & 1.99 & 7.25 & 6.53 & 2.97 & 7.47 & 8.70 & 2.56 & 6.38 & 5.82 & 17.20 & 9.27 \\
\hline $\mathrm{Sr}$ & 533.80 & 58.11 & 89.56 & 100.34 & 314.74 & 115.40 & 99.70 & 178.01 & 147.81 & 94.00 & 157.33 \\
\hline $\mathrm{Ba}$ & 466.20 & 347.40 & 451.70 & 421.50 & 343.60 & 641.70 & 808.30 & 674.60 & 536.60 & 131.00 & 462.81 \\
\hline $\mathrm{Y}$ & 15.95 & 11.22 & 16.24 & 26.15 & 21.47 & 19.54 & 23.71 & 44.54 & 23.09 & 68.60 & 44.15 \\
\hline $\mathrm{Zr}$ & 334.40 & 97.36 & 119.10 & 264.88 & 257.33 & 164.48 & 148.83 & 129.90 & 142.80 & 585.00 & 608.23 \\
\hline $\mathrm{Nb}$ & 11.67 & 9.38 & 8.08 & 9.92 & 11.12 & 9.84 & 11.79 & 8.22 & 6.32 & 38.60 & 37.88 \\
\hline $\mathrm{Ta}$ & 0.87 & 1.06 & 0.97 & 1.24 & 1.18 & 1.25 & 1.32 & 1.14 & 0.73 & 2.02 & 3.01 \\
\hline $\mathrm{Hf}$ & 2.89 & 3.15 & 3.48 & 9.34 & 9.30 & 7.65 & 7.22 & 3.76 & 4.26 & 11.99 & 13.88 \\
\hline $\mathrm{La}$ & 16.35 & 26.40 & 24.16 & 35.22 & 31.38 & 31.33 & 27.21 & 26.17 & 25.70 & 61.85 & 51.48 \\
\hline $\mathrm{Ce}$ & 37.46 & 55.40 & 51.65 & 76.09 & 65.84 & 67.79 & 59.64 & 55.45 & 51.20 & 114.90 & 112.39 \\
\hline $\operatorname{Pr}$ & 4.26 & 5.49 & 5.19 & 8.45 & 7.25 & 7.16 & 6.54 & 5.64 & 5.02 & 11.98 & 13.23 \\
\hline $\mathrm{Nd}$ & 15.46 & 21.70 & 21.03 & 32.72 & 29.94 & 27.46 & 25.38 & 24.34 & 20.50 & 47.00 & 46.25 \\
\hline $\mathrm{Sm}$ & 3.05 & 4.45 & 4.57 & 7.48 & 6.32 & 5.70 & 4.73 & 5.14 & 3.92 & 8.90 & 10.54 \\
\hline $\mathrm{Eu}$ & 1.48 & 0.30 & 0.43 & 0.61 & 1.26 & 0.52 & 0.79 & 0.68 & 0.63 & 0.86 & 0.88 \\
\hline $\mathrm{Gd}$ & 2.50 & 3.74 & 3.46 & 6.50 & 5.61 & 4.78 & 4.90 & 4.85 & 3.46 & 9.29 & 10.53 \\
\hline $\mathrm{Tb}$ & 0.50 & 0.55 & 0.56 & 1.10 & 0.85 & 0.72 & 0.80 & 0.93 & 0.63 & 1.45 & 1.60 \\
\hline Dy & 3.80 & 2.56 & 3.09 & 7.27 & 5.84 & 5.17 & 4.90 & 5.74 & 3.35 & 9.07 & 8.47 \\
\hline Ho & 0.75 & 0.49 & 0.59 & 1.28 & 1.19 & 1.03 & 1.19 & 1.38 & 0.77 & 1.91 & 1.54 \\
\hline $\mathrm{Er}$ & 2.50 & 1.33 & 1.84 & 4.10 & 3.27 & 3.51 & 3.37 & 4.84 & 2.45 & 5.53 & 3.78 \\
\hline $\mathrm{Tm}$ & 0.36 & 0.21 & 0.27 & 0.64 & 0.50 & 0.55 & 0.51 & 0.74 & 0.35 & 0.41 & 0.61 \\
\hline $\mathrm{Yb}$ & 2.62 & 1.55 & 2.11 & 4.21 & 3.49 & 3.38 & 3.91 & 5.07 & 2.53 & 6.06 & 3.31 \\
\hline $\mathrm{Lu}$ & 0.40 & 0.22 & 0.30 & 0.68 & 0.60 & 0.58 & 0.64 & 0.70 & 0.36 & 0.98 & 0.51 \\
\hline $\mathrm{Pb}$ & 16.70 & 6.20 & 8.80 & 16.32 & 19.70 & 12.70 & 25.42 & 14.10 & 6.00 & 19.00 & 67.40 \\
\hline Th & 6.17 & 17.20 & 15.27 & 25.96 & 18.17 & 26.51 & 14.30 & 12.14 & 11.42 & 16.00 & 21.02 \\
\hline $\mathrm{U}$ & 2.07 & 2.72 & 2.56 & 6.49 & 3.98 & 3.86 & 3.47 & 3.07 & 3.06 & 2.99 & 3.45 \\
\hline
\end{tabular}

Notes. Solontsovsky volcano samples: 2-1 K - zeolite-clay rock in deluvium with the marks of being eaten by animals (kudurite), kudur no. 2; 3-1 K zeolite-smectite rock in deluvium with the marks of being eaten by animals, kudur no. 3 (Bolshoi Shanduisky); 3-2 - zeolitised vitric tuff of rhyolite from an outcrop, kudur no. 3 (Bolshoi Shanduisky); 3-3 - the same from a different layer; 4-1 K - zeolite-clay rock in deluvium with the marks of being eaten by animals, kudur no. 4; 4-2 - pelitic tuffite from an outcrop. kudur no. 4; 5-5 K - zeolite-clay rock in deluvium with the marks of being eaten by animals, kudur no. 5 (Nechet); $1 \mathrm{~A}$ and 4A - Manchurian deer excrements (coprolites) gathered near Bolshoi Shanduisky kudur, Vanchinskaya Basin samples: 7-14 K - zeolite-clay rock in deluvium with the marks of being eaten by animals, kudur no. 9; 8-17 $\mathrm{K}$-i.e. kudur no. 11 . 

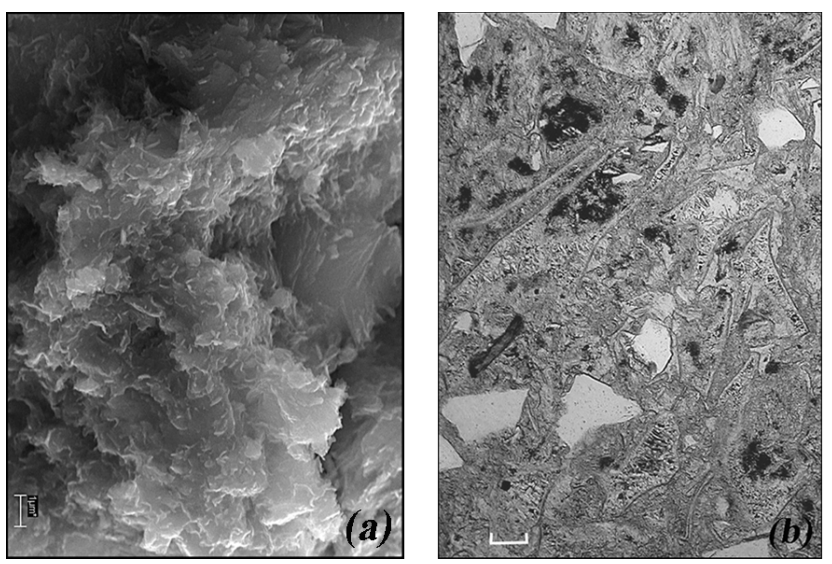

Figure 8. Zeolite microcrystals on glass: (a) sample 3-1 (vitric rhyolite tuff) under an electron microscope. There is a practically complete replacement of volcanic glass with zeolite-smectite aggregates. The dimension of scale is $1 \mu \mathrm{m}$. (b) Sample 4-2 (crystal vitric rhyolite tuff) under thin section. Zeolites are developed along the "hecks" of the volcanic glass. The dimension of scale is $50 \mu \mathrm{m}$.

be close to the coarse tuffs and rhyolite ignimbrites in terms of their chemical composition (Table 1).

By comparing the data on volcanism and zeolite mineralisation in the Vanchinskaya Basin and Solontsovsky palaeovolcano, it can be observed that the processes of zeolite formation in the studied volcanic masses, although different in terms of their morphology, geological structure and age, share a number of common features determined by the geochemical type of felsic explosive volcanism that has developed there.

The volcanic and tuffaceous sedimentary rocks of the basin are characterised by significant variations in their concentrations of trace elements (Table 2).

Alterations in the rocks studied were manifested by the hydrothermal changes in tuffaceous sedimentary rocks, vitric tuffs and rock glass. These changes were controlled by the discharge zones, both linear (Vanchinskaya Basin) and focal (Solontsovsky volcano) types, along which hydrothermal fluids circulated, ascending from near-surface magma chambers. The formation of gold-silver Soyuznoe deposit at the eastern side of the Vanchinskaya Basin and the Tayozhnoe silver deposit at the northern side of the Solontsovsky palaeovolcano was related to this process.

Trace element upper crust normalised patterns of the tuffs, rhyolite ignimbrites and lacustrine-caldera ashy deposits, show a high degree of concordance between each other, with specific distinct minima of $\mathrm{Sr}, \mathrm{P}, \mathrm{Ti}$ and $\mathrm{Tb}$. Rare-earth element distributions in tuffs, rhyolite ignimbrites and lacustrine ashy deposits, normalised to chondrite, are also close to each other. They are characterised by a distinct europium minimum.

Why do animals living in certain areas of the Sikhote-Alin dig up and consume rocks with a high concentration of zeo-
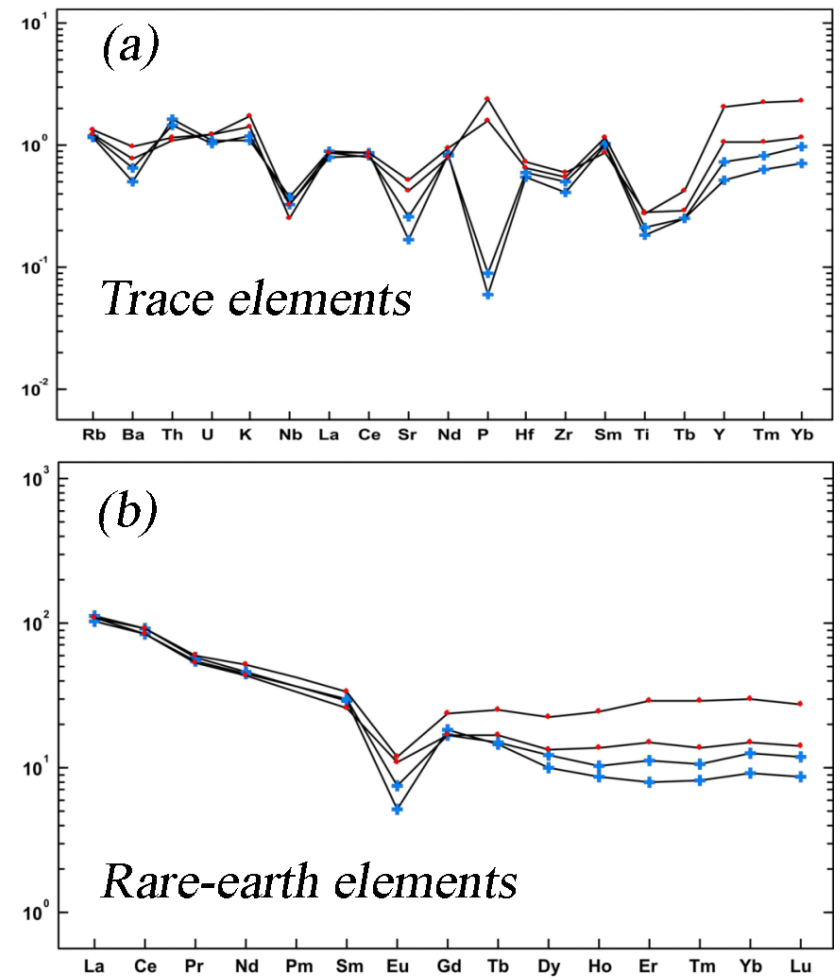

Figure 9. Concentrations of incompatible and rare-earth elements normalised to the composition of the upper crust (according to Taylor et al., 1981) and chondrite (for rare-earth elements, according to Sun and McDonough, 1989) in coprolites and source kudurites from the Solontsovsky palaeovolcano. Coprolite and kudurite data are denoted by points and crosses, respectively.

lites? This question was raised by us long ago, but no definite answer to it has yet emerged. At the same time, it may be noted that a general concept of geophagy among animals and people was already developed (Panichev, 2011; Panichev et al., 2013).

The first and easiest assumption, which any researcher exploring this problem should consider, is that zeolites contain a significant stock of sodium ions with exchange potential that can easily be released in the electrolytes of animals' gastrointestinal tracts, displacing potassium ions, which are in excess there. The widely known hankering of ruminant animals for sodium salt supports this explanation.

The hypothesis about the active release of sodium exchangeable ions from zeolite-containing kudurites in the gastrointestinal tract was verified by us long ago after special experiments with artificial electrolytes (Panichev et al., 2012) as well as by a direct quantitative balance calculation based on coprolite silicate analysis (fossilised faeces) and analogous kudurites (Panichev, 1990). The data acquired using both methods are in close agreement.

To confirm the hypothesis, let us refer to the results of the quantitative comparison of the chemical compositions of 
Table 3. The results of comparing the chemical compositions of kudurites and analogous coprolites gathered in the area of the Bolshoi Shanduisky kudur.

\begin{tabular}{lrrrrrrrrrr}
\hline Sample & \multicolumn{10}{c}{ Oxides } \\
\cline { 2 - 10 } & $\mathrm{SiO}_{2}$ & $\mathrm{TiO}_{2}$ & $\mathrm{Al}_{2} \mathrm{O}_{3}$ & $\mathrm{Fe}_{2} \mathrm{O}_{3}$ & $\mathrm{MnO}$ & $\mathrm{MgO}$ & $\mathrm{CaO}$ & $\mathrm{Na}_{2} \mathrm{O}$ & $\mathrm{K}_{2} \mathrm{O}$ & $\mathrm{P}_{2} \mathrm{O}_{5}$ \\
\hline 3-1 & 76.52 & 0.12 & 13.55 & 2.11 & 0.03 & 0.31 & 1.16 & 2.05 & 4.14 & 0.01 \\
3-3 & 75.84 & 0.14 & 13.75 & 1.67 & 0.04 & 0.27 & 1.40 & 2.49 & 4.37 & 0.03 \\
Average in kudurites & 76.18 & 0.13 & 13.65 & 1.89 & 0.04 & 0.29 & 1.28 & 2.27 & 4.26 & 0.02 \\
1A & 72.52 & 0.20 & 14.10 & 1.72 & 0.26 & 0.47 & 2.20 & 1.41 & 6.79 & 0.32 \\
4A & 72.50 & 0.21 & 14.10 & 1.84 & 0.12 & 0.68 & 2.71 & 1.30 & 5.96 & 0.51 \\
Average in coprolites & 72.51 & 0.20 & 14.10 & 1.78 & 0.19 & 0.57 & 2.45 & 1.35 & 6.36 & 0.41 \\
Difference & -3.67 & +0.07 & +0.45 & -0.11 & +0.12 & +0.28 & +1.17 & -0.92 & +2.10 & +0.39 \\
Difference, \% & -4.81 & +53.84 & +3.29 & -5.82 & +300 & +96.55 & +91.40 & -40.52 & +49.29 & +1950 \\
\hline
\end{tabular}

Notes. Ignition losses are proportionally distributed. "-" - subtraction of element from kudurite; “+” - addition of element to kudurite in the gastrointestinal tract environment.

zeolite-containing kudurites and coprolites that we gathered in the area of the Bolshoi Shanduisky kudur (Table 3).

Table 3 shows that the content of sodium in the rock comprises approximately $9 \mathrm{~g} \mathrm{~kg}^{-1}$. This marker is quite typical for zeolite-containing kudurites and is definitely significant when we consider that one Far Eastern red deer eats up to $10 \mathrm{~kg}$ of kudurite on average per season. Meanwhile, the sodium in the kudurite in the gastrointestinal tract conditions definitely exchanges with potassium ions (see Table 3 , gross data). The fact is that, along with the sodium from kudurites, a considerable amount of silicon oxide is released into the gastrointestinal tract (more than $35 \mathrm{~g} \mathrm{~kg}^{-1}$ of eaten rock). It can be explained by the fragmentary subtraction of its ultrafine particles, which leaves the rock and spreads along the gastrointestinal tract.

Upon further analysis of Table 3, it is clear that zeolite does more in the gastrointestinal tract than simply supply sodium ions or other chemical elements (in this case, for example, iron). It is also a natural sorbent, which apparently works directly to actively absorb potassium along with a number of other elements, the largest percentages of which are made up by phosphorus, calcium, magnesium and manganese (see Table 3). This action of zeolite can be understood as a cost that animals must endure to acquire $\mathrm{Na}$ in exchange for a more deficient element.

However, the results in Table 2 also reveal that there are equally complex interactions between kudurites and coprolites according to microelements. Moreover, the most interesting facts, from our perspective, emerge when we compare kudurite-coprolite analogues in the spectrum of incompatible and rare-earth elements (these results are plotted for better visualisation in Fig. 9). The diagram shows that the elements that are actively released from the gastrointestinal tract, in addition to phosphorus, are $\mathrm{Ba}, \mathrm{Sr}$ and practically all heavy rare-earth elements.

Thus, the character of the interaction between kudurites and electrolytes in the gastrointestinal tract provides evidence that the "sodium hypothesis" offers one poten- tial explanation for this. This impression is strengthened if we recall that zeolite-containing kudurites are less widely distributed in other regions of the world than chloritehydromica varieties, which rarely contain salts or sodium ions in sufficient amounts to compensate for the periodic deficit of this element in an animal's body (Panichev, 1990). The sodium hypothesis fails to explain why musk deer, whose basal feed (epiphytic lichen) species has the lowest sodium level compared to forage plants for duplicidentates, deer and elk (in practically any other habitats), totally neglect the sodium-containing kudurs.

Our data based on comparison of zeolite-containing kudurs with coprolites rather suggests that the main reason for kudurite consumption in the Sikhote-Alin is connected with the animals' urge to discard excessive and toxic concentrations of certain elements that are widespread in specific habitats and ingested with forage plants. At the same time, the purging of such elements is apparently provided by the absorption properties of not only the zeolites themselves but also the silicon oxide gels, and possibly also the aluminium, iron and magnesium oxides formed in the alkaline conditions of the gastrointestinal tract due to the partial disintegration of the disperse phase of kudurite composition (Panichev, 2011).

One can only guess which elements animals are attempting to remove from their bodies with the help of mineral absorbent ion exchangers. In all likelihood, geophagial mechanisms of body correction can be induced by various biochemical factors, one of which probably has a direct connection with the group of rare-earth elements.

\section{Conclusions}

The primary conclusion of this research is that the majority of the kudurs of the eastern Sikhote-Alin (and, presumably, analogous situations that will be found in other volcanic areas) are formed from the zeolite-bearing volcanic and volcano-sedimentary rocks, glassy rhyolite in most cases, 
within the borders of the Cenozoic rift-related basins and calderas. The association of kudur landscape complexes with the manifestations of the Cenozoic felsic volcanism predetermines their localisation at the Cenozoic volcanic edifices of the eastern Sikhote-Alin.

In summary, we should particularly note that our attempt to understand the spectrum of problems touched upon here at the junction of geology and biology once again confirms the importance of scientific research in this area, as well as the need to broaden the cooperation between specialists in geology and biology (Golokhvast et al., 2014).

Data availability. No data sets were used in this article.

Author contributions. Alexander M. Panichev and Vladimir K. Popov conceived and designed the experiments; Igor Yu. Chekryzhov performed the experiments; Alexander M. Panichev, Vladimir K. Popov and Igor Yu. Chekryzhov analyzed the data; Ivan V. Seryodkin and Kirill S. Golokhvast contributed reagents, materials and analysis tools; Alexander M. Panichev, Alexander A. Sergievich and Kirill S. Golokhvast wrote the paper.

Competing interests. The authors declare that they have no conflict of interest.

Acknowledgements. The authors express gratitude to the management of the Sikhote-Alinsky Biospheric Reserve and especially to director D. G. Gorshkov. Kirill S. Golokhvast received funding through a Grant of the President of the Russian Federation (MD7737.2016.5)

Edited by: S. Fontaine

Reviewed by: N. P. Bgatova and one anonymous referee

\section{References}

Andreeva, E. D. and Kim, A. U.: About zeolites of some epithermal gold-silver deposits of Kamchatka, in VI regional youth scientific conference "Researches in the field of sciences about Earth (geography, geology, geophysics, geoecology, volcanology)", 2627 November, Petropavlovsk-Kamchatsky, Russia, 13-20, 2008 (in Russian).

Chekryzhov, I. Y., Popov, V. K., Panichev, A. M., Seredin, V. V., and Smirnova, E. V.: New data on the stratigraphy, volcanism, and zeolite mineralization of the cenozoic Vanchinskaya depression in Primorye, Russ. J. Pac. Geol., 4, 314-330, 2010.

Elpatievsky, P. V. and Panichev, A. M.: Geochemical peculiarities of the Sikhote-Alin animal solonetz, Bulletin of Moscow Society of Naturalists, Biological series, 85, 12-23, 1980 (in Russian).

Golokhvast, K., Sergievich, A., and Grigoriev, N.: Geophagy (Rock Eating), Experimental Stress and Cognitive Idiosyncrasy, Asian Pacific Journal of Tropical Biomedicine, 4, 362-366, 2014.
Grebennikov, A. V. and Popov, V. K.: Petrogeochemical Aspects of the Late Cretaceous and Paleogene Ignimbrite Volcanism of East Sikhote-Alin, Russian J. Pac. Geol., 8, 38-55, 2014.

Kaplanov, L. G.: Tiger. Manchurian deer. Moose, Moscow Society of Naturalists, Moscow, 128, 1948 (in Russian).

Kononenko, N. A.: Late Paleolithic and Neolithic Periods in Primorye: Problems of Origin and Intercommunication of Ancient Cultures, in: Prehistory and Ancient History, Seoul, 4, 153-166, 1993.

Korotkiy, A. M.: About reorganization of the Sikhote-Alin hydrographic system plan, in: Voprosy geologii I okeanologii sovetskogo sektora Tikhookeanskogo podvizhnogo poyasa, Vladivostok, 315-322, 1968 (in Russian).

Otofuji, Y. I., Matsuda, T., Itaya, T., Shibata, T., Matsumoto, M., Yamamoto, T., Morimoto, C., Kulinich, R. G., Zimin, P. S., Matunin, A. P., Sakhno, V. G., and Kimura, K.: Late cretaceous to early Paleogene paleomagnetic results from Sikhote Alin, Far Esatern Russia: implications for deformation of East Asia, Earth Planet. Sc. Lett., 130, 95-108, 1995.

Otofuji, Y. I., Matsuda, T., Enami, R., Uno, K., Nishihama, K., Su, L., Kulinich, R. G., Zimin, P. S., Matunin, A. P., and Sakhno, V. G.: Internal de-formation of Sikhote Alin volcanic belt, Far Eastern Russia: Paleogene paleomagnetic results, Tectonophysics, 350, 181-192, 2002.

Panichev, A. M.: Lithophagy in the human and animal world, Publ. House "Nauka", Moscow, 215, 1990 (in Russian).

Panichev, A. M.: Lithophagy. Geological, ecological and biomedical aspects, Publ. House "Nauka", Moscow, 149, 2011 (in Russian).

Panichev, A. M., Popov, V. K., Chekryzhov, I. Y., Golokhvast, K. S., and Seryodkin, I. V.: Kudurs of Solontsovsky paleovolcano in Tayozhnaya river basin, Eastern Sikhote-Alin, Achievements in the Life Sciences, 5, 7-28, 2012 (in Russian).

Panichev, A. M., Golokhvast, K. S., Gulkov, A. N., and Chekryzhov, I. Y.: Geophagy and geology of mineral licks (kudurs): a review of russian publications, Environmental Geochemistry and Health, 35, 133-152, 2013.

Pearce, J. A., Harris, N. B. W., and Tindle, A. G.: Trace element discrimination diagrams for the tectonic interpretation of granitic rocks, J. Petrol., 25, 956-983, 1984.

Popov, V. K., Simanenko, V. P., and Sakhno, V. G.: East SikhoteAlin volcanic-plutonik belt (Late Cenomanian-Maastrichtian), Volcanic formations, in: Geodinamics, magmatism and metallogeny of the Russian East: in 2 books, edited by: Khanchuk, A. I., Vladivostok: Dalnauka, Book 1, 273-281, 2006.

Pushcharovsky, D. Yu.: Minerals X-ray analysis, Publ. House "Geoinformmark", Moscow, 292, 2000 (in Russian).

Seredin, V. V. and Shpirt, M. Y.: Rare earth elements in the humic substance of metalliferous coals, Lithol. Miner. Resour., 3, 281286, 1999.

Sun, S. S. and McDonough, W. F.: Chemical and isotopic systematics of ocean basalts implications for mantle composition and processes, Magmatism in ocean basin, edited by: Saunders, A. D. and Norry, M. J., Geol. Soc. London. Spec. Pub. B, 42, 313345, 1989.

Taylor, S. R., McLennan, S. M., Armstrong, R. L., and Tarney, J.: The composition and evolution of the continental crust: rare earth element evidence from sedimentary rocks, Philos. T. R. Soc., 301, 381-399, 1981. 
Tomson, I. N., Polyakova, O. P., Sidorov, A. A., and Alekseev, V. Y.: Soyuznoe gold-silver deposit in Primorye and its prospects (Russia), Geol. Ore Deposit., 44, 304-313, 2002.

Vetrennikov, V. V.: Geological structure of the Sikhote-Alin state reserve and the cenral Sikhote-Alin, in Scientific Papers of SikhoteAlin Biosphere Reserve, Vol. VI. Vladivostok: Far East Book Publishing House, 167, 1976 (in Russian).
Young, S.: Craving Earth: Understanding Pica: the Urge to Eat Clay, Starch, Ice, and Chalk, Columbia University Press, New York, 2011.

Zaumislova, O. J. and Panichev, A. M.: Licks as a Component of Environment of the Ussuryi Elk, in Proceedings III International Moose Symposium: Syktyvkar, USSR, 55, 1990 (in Russian). 